\title{
Ear atresia: Is there a role of apoptosis-regulating miRNAs?
}

\author{
Ezgi Aslan, ${ }^{1}$ Emre Akbas, ${ }^{1}$ Sena Yilmaz, ${ }^{1}$ Ahmet Salih Karaoglu, ${ }^{1}$ Ubeyde Telli, ${ }^{1}$ Salih Yildirim, ${ }^{1}$ \\ Hilal Gudek, ${ }^{1}$ Mahmut Tayyar Kalcioglu, ${ }^{2}$ Sarenur Yilmaz, ${ }^{3}$ Ibrahim Akalin $^{3}$ \\ ${ }^{1}$ Istanbul Medeniyet University Faculty of Medicine, Istanbul, Turkey \\ ${ }^{2}$ Department of Otorhinolaryngology, Istanbul Medeniyet University Faculty of Medicine, Istanbul, Turkey \\ ${ }^{3}$ Department of Medical Genetics, Istanbul Medeniyet University Faculty of Medicine, Istanbul, Turkey
}

\begin{abstract}
OBJECTIVE: The molecular events underlying ear development involve numerous regulatory molecules; however, the role of microRNAs (miRNAs) has not been explored in patients with ear atresia. Here, we aimed to investigate the expressions of 20-22 nucleotide noncoding RNAs.

METHODS: We selected 12 miRNAs that function to control post-transcriptional gene expression in different pathways, including apoptosis, angiogenesis, and chondrogenesis. The altered miRNA expressions were analyzed by real-time PCR from serum samples of 7 patients with ear atresia and 8 controls.

RESULTS: We found that the expression of apoptosis-regulating miRNAs was significantly downregulated in patients with ear atresia. The expressions of miR126, miR146a, miR222, and miR21 were significantly decreased by $76.2-(p=0.041), 61.8$ $(p=0.000), 30.5-(p=0.009)$, and 71.21 -fold $(p=0.042)$, respectively, compared with controls.

CONCLUSION: Abnormal ear development in ear atresia patients, could possibly be due to the reduced expression of apoptosis regulating miRNAs. Changes in the regulation of tumor protein p53 (TP53), p53 upregulated modulator of apoptosis (PUMA), Fas cell surface death receptor (FAS), FAS ligand (FasL), and phosphatase and tensin homolog (PTEN) directly or within the apoptosis-related cascades may play important roles during development, particularly in the external ear. This is the first report to present the possible association between apoptosis-regulating miRNAs and ear atresia/microtia.
\end{abstract}

Keywords: Apoptosis; ear atresia; miRNA; miR21; miR146a; miR126b; miR222.

Cite this article as: Aslan E, Akbas E, Yilmaz S, Karaoglu AS, Telli U, Yildirim S, et al. Ear atresia: Is there a role of apoptosis-regulating miRNAs? North Clin Istanb 2018;5(3):238-245.

$\mathrm{E}$ ar atresia is a spectrum of ear deformities, commonly coexisting with unilateral or bilateral microtia (MIM 600674, MIM 251800). Its prevalence is between 0.8 and 17.4 in 10,000 individuals in different populations $[1,2]$. It involves the failure of the development of the external auditory canal (EAC), and its surgical treatment is considered to be one of the most complex and demanding surgeries in otorhinolaryngology. Moreover, this malformation may be associated with other congenital anomalies, including the CHARGE syndrome $[3,4]$.
Development of the ear is a continuous complex process that begins during early embryonic life within three compartments and is completed till the first decade [5]. Briefly, in the $4^{\text {th }}$ to $5^{\text {th }}$ week of embryogenesis, the ectoderm of the first branchial groove elongates to form the primitive EAC and oppose to the endoderm of the first pharyngeal pouch to form a prototympanic membrane where the mesoderm intervenes between them thereafter. By this time, the epithelial plate produced by the proliferation of the ectodermal cells lining the primitive

Received: August 02, 2017 Accepted: December 11, 2017 Online: September 13, 2018

Correspondence: Dr. Ibrahim AKALIN. Istanbul Medeniyet Universitesi Tip Fakultesi, Tibbi Genetik Anabilim Dali, Istanbul, Turkey. Phone: +902165954000 e-mail: ibrahimakalin@yahoo.com

(c) Copyright 2018 by Istanbul Provincial Directorate of Health - Available online at www.northclinist.com 
EAC first occludes the primitive EAC in the $8^{\text {th }}$ week of gestation and is eventually split by apposed epithelial cells for subsequent recanalization to secondary EAC by approximately $19^{\text {th }}-21^{\text {st }}$ week of gestation. Toward the end of the $28^{\text {th }}$ week, the tissue is progressively absorbed from the tympanic space and branchial groove to open the external canal in essence with the remaining tympanic membrane [6] and closely allied with the development of the middle ear space and ear bones from the branchial apparatus $[7,8]$.

The remarkable role of programmed cell death, the-socalled apoptosis, in ear development has been deduced by advances in recent technology. It aids in normal development by eradicating unwanted cells during morphogenesis. Neural tube, palate, heart, duodenal mucosa, and limb bud are the clarified examples in which apoptosis occurs $[9,10]$. Likewise, Nishizaki et al. [8] (1998) showed that apoptosis is involved in the mouse EAC development.

Microribonucleic acids (miRNAs) are highly conserved, small, noncoding RNA molecules, which are approximately 21-24 nucleotides in length, and control post-transcriptional gene expression in a wide variety of cellular processes, including cell proliferation, differentiation, cell fate determination, signal transduction, organ development, angiogenesis, tumorigenesis, and apoptosis [11-13]. Many miRNAs are involved in regulating either intrinsic or extrinsic apoptotic pathways [14].

The normal development of the ear consists of complex succession of events occupying three embryonic germ cell layers. Factors leading to ear atresia by ceasing the contemporaneous aural developmental course are yet to be clarified. Nishikazi et al. [8] (1998) showed that in mouse, the apposed epithelium of EAC is eliminated by apoptosis. Hence, in this study, we aimed to investigate the expression of miRNAs regulating several pathways, including apoptosis, and for the first time achieved significantly altered expressions of miRNAs in the serum of patients with ear atresia, up to the literature.

\section{MATERIALS AND METHODS}

\section{Patient and control groups and miRNA}

In our study, we included 7 patients and 8 controls who were age- and sex-matched after obtaining local ethical committee approval (2013-0007) and informed consents. The mean age of the patients was $14.3 \pm 7.9$ years (minimum, 5 years; maximum, 27 years). Four patients had unilateral ear atresia, while the rest had bilateral ear atresia. The investigated miRNAs regulating different mechanisms are shown in Table 1 .

\section{Isolation of miRNA-enriched total RNA}

MiRNAs were isolated from the serum samples of the patients and controls using the miRNeasy Serum/Plasma Kit (Qiagen) according to manufacturer's instructions. Briefly, $1 \mathrm{ml}$ of QIAzol Lysis Reagent was added to 200 $\mu \mathrm{l}$ of the serum sample by pipetting up and down for efficient lysis of fatty and standard tissues before RNA isolation. The homogenate was incubated at room temperature for 5 minutes. Then, $3.5 \mu \mathrm{l}$ of miRNeasy Serum/Plasma Spike-In Control (at $1.6 \times 108$ copies $/ \mu \mathrm{l})$ was added and mixed thoroughly. Next, $200 \mu$ l chloroform was added to

TABLE 1. miRNA regulating different mechanisms in ear atresia

\begin{tabular}{|c|c|c|c|c|}
\hline & Apoptosis Regulator & Endodermal Developer & Angiogenesis & Chondrogenesis \\
\hline hsa-mir-143 & $x$ & & & \\
\hline hsa-mir-146a & $\mathrm{X}$ & & & \\
\hline hsa-mir-92a & $x$ & & & \\
\hline hsa-mir-181b & $x$ & & & \\
\hline hsa-mir-210 & $x$ & & & \\
\hline hsa-mir-106b & $x$ & & & \\
\hline hsa-mir-183 & $\mathrm{x}$ & & & \\
\hline hsa-mir-375 & & $x$ & & \\
\hline hsa-mir-126 & & & $x$ & \\
\hline hsa-mir-222 & $x$ & & & \\
\hline hsa-let-7f & & & & $x$ \\
\hline hsa-mir-21 & $x$ & & & \\
\hline
\end{tabular}


the lysate tube, vortexed for 15 seconds, and incubated at room temperature for 2 minutes. This was followed by the separation of the phases by centrifugation at $12000 \times \mathrm{g}$ at $4^{\circ} \mathrm{C}$ for 15 minutes. Then, $600 \mu \mathrm{l}$ of the upper aqueous phase was transferred to a new collection tube by avoiding the transfer of any interphase solution. Ethanol $(900 \mu \mathrm{l})$ was added and mixed thoroughly using a pipette. Next, $700 \mu \mathrm{l}$ of the sample was added onto an RNeasy MinElute spin column in a $2-\mathrm{ml}$ collection tube and centrifuged at $\geq 8000 \times$ g for 15 seconds at room temperature. Buffers RWT $(700 \mu \mathrm{l})$, and RPE $(500 \mu \mathrm{l})$ and $80 \%$ ethanol $(500 \mu \mathrm{l})$ prepared with RNase-free water were added to the RNeasy MinElute spin column and centrifuged for 15 seconds at $\geq 8000 \times$ g, followed by additional 2 minutes of centrifugation at full speed for 5 minutes to dry the membrane. The filtrate and collection tube were discarded at each step. Finally, the microRNA-enriched total RNA was eluted by centrifugation for 1 minute at full speed using $14 \mu \mathrm{l}$ of RNase-free water.

\section{Complementary DNA (cDNA) synthesis}

cDNA was randomly primed using miScript II Reverse Transcription (RT) Kit (Qiagen) using $5 \mu \mathrm{g}$ of miRNAenriched total RNA. Briefly, RT-PCR was set up with $4 \mu \mathrm{l}$ of $5 \times$ miScript HiSpec Buffer, $2 \mu$ of $10 \times$ Nucleic Mix, 1 $\mu \mathrm{l}$ of miScript Reverse Transcriptase Mix, $8 \mu$ l of RNasefree water, and $5 \mu \mathrm{l}$ of template RNA in a $20-\mu \mathrm{l}$ reaction tube. Reverse transcription was carried out at $37^{\circ} \mathrm{C}$ for 60 minutes and $95^{\circ} \mathrm{C}$ for 5 minutes. cDNA was then diluted with $200 \mu \mathrm{l}$ of nuclease free water for further use in realtime polymerase chain reaction (RT-PCR).

\section{RT-PCR}

Mature miRNAs were expressed using Rotor-Gene $e^{\circledast} \mathrm{Q}$ instrument with software 2.1.0.9 and quantitative RTPCR (RT-qPCR) with QuantiTech SYBR Green PCR Kit (Qiagen). RT-PCR was performed in duplicate after optimization, including minus reverse transcription controls to assess any DNA and nontemplate controls for ensuring the lack of background signal. The RT-PCR reaction was set up with mild modifications of manufacturer's instructions as follows: $5 \mu \mathrm{L}$ of $2 \times$ QuantiTect SYBR Green PCR Master Mix , $1 \mu \mathrm{L}$ of $10 \times$ miScript Universal Primer, $1 \mu \mathrm{L}$ of $10 \times$ primer assay, and $1 \mu \mathrm{L}$ of RNase-free water. Thirteen miRNAs covering a variety of miRNA sequence features (Table 1), including Ce miR-39, were selected, and SNORD61, SNORD68, and SNORD95 were used as housekeeping genes. Shortly after the hot start Taq polymerase activation at $95^{\circ} \mathrm{C}$ for 10 minutes, reaction was carried out with 40 cycles of $95^{\circ} \mathrm{C}$ for 15 seconds, $55^{\circ} \mathrm{C}$ for 30 seconds, and $72^{\circ} \mathrm{C}$ for 15 seconds, followed by melting reaction ramps from $55^{\circ} \mathrm{C}-95^{\circ} \mathrm{C}$ at the acquisition of Melt A on Green. For TP53 mRNA expression, forward and reverse primers 5'-CGACAGAGCGAGATTCCATCTCAA-3' and 5'-GCCCCAATTGCAGGTAAAACAGTC-3' were used, respectively.

\section{Data analysis and statistics}

The threshold was manually determined as 0.025 in all the reactions, and standards were imported from the previous study as conc $=10^{\wedge}(-0.328 \times \mathrm{C} t+11.903)$ with $c y-$ cle threshold $(\mathrm{Ct})$ values of $-3.050 \times \log ($ conc $)+36.302$ and R2 of 0.99974. Ct values of miRNA expressions were exported from the instrument after normalization with dynamic tube using slope correct options of the real-time cycler software. $\mathrm{Ct}$ values and calculated concentrations according to the standards were entered into an Excel spreadsheet, and the average $\mathrm{Ct}$ value was converted to quantities for SABiosciences analysis. The quality of expended mature miRNAs was checked with melt analyses on Green. Then, the $\mathrm{Ct}$ data of miRNAs and TP53 mRNA were analyzed according to fold change [2- $\left.{ }^{-\Delta \Delta C T}\right]$ using online miScript miRNA PCR Array Data Analysis Tool (www.qiagen.com). For TP53 mRNA expression analyses, the Student's t-test was used. A p-value of 0.05 was considered statistically significant.

\section{RESULTS}

\section{RT-qPCR analysis of serum miRNA}

To explore the possible effects of microRNAs in the ear atresia, 13 microRNA expression profiles were analyzed in the serum of patients and control group. We found the expression patterns of pro-apoptotic microRNA's downregulated in the patients. Among them, miR-126, miR$146 \mathrm{a}$ and miR-222 and miR-21 were significantly 76.2 $(p=0.041), 61.8(p=0.000), 30.5(p=0.009)$ and 71,21 $(\mathrm{p}=0.042)$ fold decreased compared to controls, respectively (Table 2 and Fig. 1).

\section{TP53 mRNA expression analysis}

To explore the effects of downregulated pro-apoptotic miRNAs on apoptosis, we analyzed the expression levels of TP53 mRNA in the patient's serum. We found that TP53 mRNA expression was significantly downregulated (31.7-fold; $p=0.036$; CI95\%, 0.00001-0.09) in patients with ear atresia compared with controls. (Figs. 2, 3). 
TABLE 2. Fold-regulation results and p-values of miRNAs expression levels of the ear atresia and control groups. Statistically significant and lower miRNAs expressions according to the control group are indicated with "a" symbol and "-," respectively.

\begin{tabular}{lcccc} 
& $\begin{array}{c}\text { Fold Change } \\
\text { Ear Atresia/Control }\end{array}$ & $95 \%$ CI & $\begin{array}{c}\text { Fold Regulation } \\
\text { Ear Atresia/Control }\end{array}$ & $p$ \\
\hline hsa-mir-39ce & 1 & $(1.00-1.00)$ & 1 & 0 \\
hsa-mir-143 & 0.37 & $(0.00001-0.90)$ & -2.7 & 0.34 \\
hsa-mir-210 & 2.66 & $(0.00001-9.28)$ & 2.6 & 0.96 \\
hsa-mir-375 & 0.03 & $(0.00001-0.06)$ & -33.8 & 0.11 \\
hsa-mir-146a & $0.02^{\mathrm{a}}$ & $(0.00001-0.04)^{\mathrm{a}}$ & $-61.8^{\mathrm{a}}$ & $0.0003^{\mathrm{a}}$ \\
hsa-mir-222 & $0.03^{\mathrm{a}}$ & $(0.00001-0.09)^{\mathrm{a}}$ & $-30.5^{\mathrm{a}}$ & $0.009^{\mathrm{a}}$ \\
hsa-mir-106b $^{\mathrm{a}}$ & 0.31 & $(0.00001-0.80)$ & -3.1 & 0.31 \\
hsa-let-7f & 0.70 & $(0.00001-3.06)$ & -1.4 & 0.21 \\
hsa-mir-183 & 0.59 & $(0.00001-1.57)$ & -1.7 & 0.35 \\
hsa-mir-181b & 0.24 & $(0.00001-0.74)$ & -4.1 & 0.14 \\
hsa-mir-126 & $0.01^{\mathrm{a}}$ & $(0.00001-0.04)^{\mathrm{a}}$ & $-76.2^{\mathrm{a}}$ & $0.041^{\mathrm{a}}$ \\
hsa-mir-92a & 0.01 & $(0.00001-0.02)$ & -130 & 0.07 \\
SNORD68 & 1.04 & $(0.00001-2.89)$ & 1 & 0.36 \\
hsa-mir-21 & $0.014^{\mathrm{a}}$ & $(0.00001-0.04)^{\mathrm{a}}$ & $-71.2^{\mathrm{a}}$ & $0.042^{\mathrm{a}}$ \\
SNORD61 & 1.55 & $(0.18-2.93)$ & 1.55 & 0.79 \\
\hline
\end{tabular}

CI: Confidence Interval

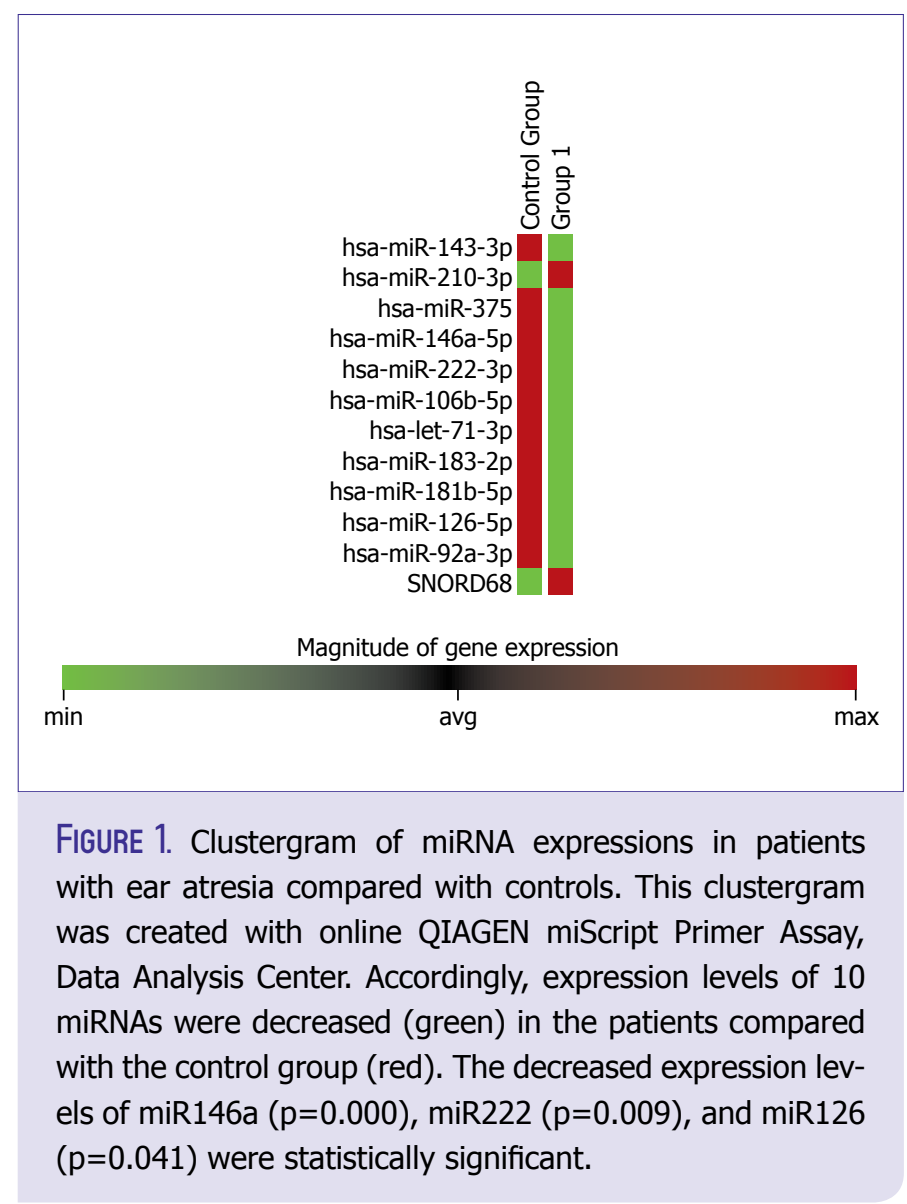

\section{DISCUSSION}

The underlying effect of miRNA on the development of ear atresia was our major query in this study. Because miRNAs have an essential role in the developmental processes, including organogenesis, we aimed to explore a possible association between miRNAs regulating inflammation, apoptosis, angiogenesis, and chondrogenesis and ear atresia to detect whether any miRNA could be responsible for the developmental defects in ears (Table 1). Here, we noticed that there was a significant expression difference for several miRNAs between patients and healthy controls. Because the ears continue to develop during the lifetime [5], and ear atresia not only presents with external ear anomaly or microtia but also affects middle and inner compartments, we decided to use the serum samples of patients to investigate miRNA expression levels at the time of diagnoses instead of taking biopsy samples from the patients' external ear. We found that the expressions of four miRNAs miR222, miR146a, miR126, and miR21 among the 12 miRNAs were significantly downregulated in patients with ear atresia. Remarkably, these miRNAs are particularly known to regulate apoptosis in human cancers.

Few studies in the literature have addressed the ques- 


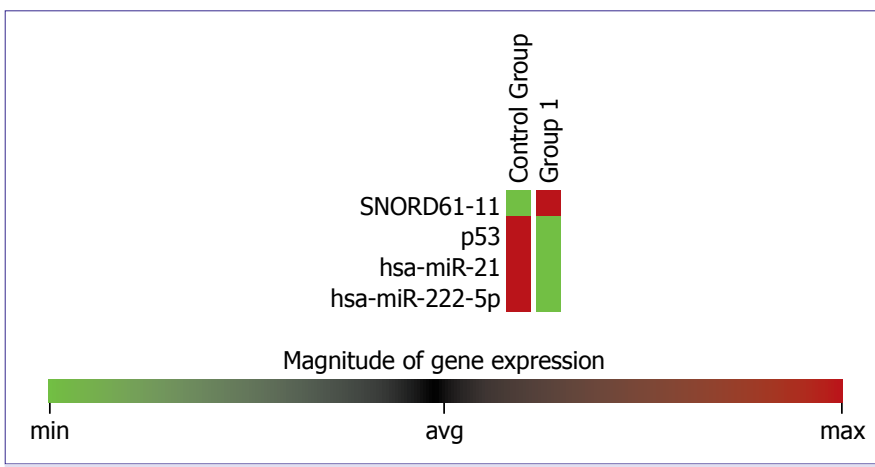

FIGURE 2. Clustergram of TP53 mRNA and miR-21 expressions in patients with ear atresia compared with the control group. Average TP53 mRNA and miR21 $(p=0.042)$ concentrations were determined in ear atresia and control groups by quantitative real-time PCR. The TP53 mRNA expressions of both the groups were compared using the t-test. TP53 $(p=0.04)$ and miR21 $(p=0.042)$ expressions were decreased significantly in the ear atresia group compared with the control group. There was no significant difference between the control and ear atresia groups in terms of SNORD61 (housekeeping gene) expression.

tion of miRNA involvement in ear atresia, but they were mostly performed on experimental animals [15-18]. In the current literature, there are clues of the possible effects of miRNAs that could play a role in normal ear development. For example, Soukup et al. [18] reported the possible role of miRNAs in ear development and that miR183 expression was closely associated with the degree of hair cell and sensory epithelium differentiation in mice. Additionally, Li et al. [17] showed that knockdown of miR183, miR96, and miR182 resulted in decreased number of hair cells in the inner ear, smaller statoacoustic ganglion, defects in semicircular canals, and abnormal neuromasts on the posterior lateral line. Moreover, Li et al. [19] (2013) showed that in the cartilages of microtia, miR451 and miR486 expressions were significantly upregulated, whereas miR200c was significantly downregulated compared with controls. Hence, these studies provided insights regarding the control of miRNAs in ear development; however, which pathways are controlled by these miRNAs needs to be explored and is essential for normal development in humans. However, our study was the first to link apoptosis-regulating miRNAs with the pathogenesis of ear atresia. miRNA expression analyses in this study revealed that significantly decreased expressions of apoptosis-regulating miRNAs may have a role in the pathogenesis of ear atresia through different loci of the apoptosis pathway (Table 2).

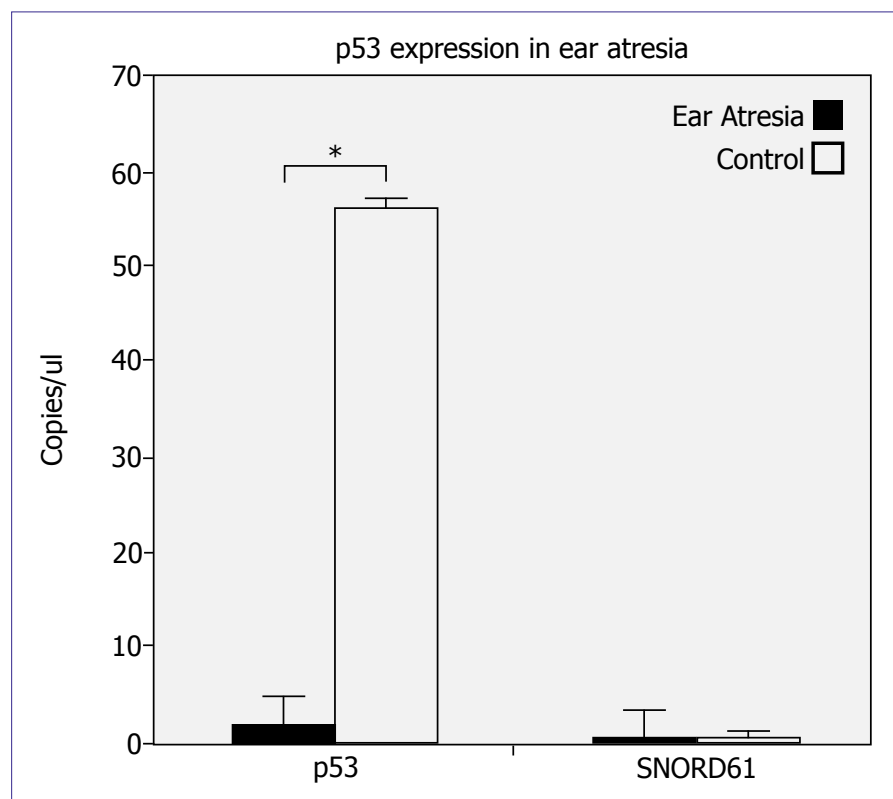

FIGURE 3. Comparison of SNORD61 (housekeeping gene) and TP53 mRNA expression levels (copy number/ $/$ l) in the serum of ear atresia and control groups. TP53 mRNA expression levels were decreased 31.7-fold (statistically significant; $p=0.04$ ) in the ear atresia group compared with the control group.

To discuss in more detail, the extrinsic apoptotic pathway starts with binding of FasL (death Ligand) to its receptor (Fas), and FasL has been reported to be a direct target of miR21 [14]. It has been reported that by targeting FasL, serum miR 21 serves as a predictor for chemosensitivity and chemoresistance in advanced pancreatic cancers [20]. Moreover, miR21 promotes cell survival by inhibiting FasL expression in acute myeloid leukemia.

Because we significantly found miR21 to be 71.2fold downregulated (95\% CI: 0.00001-0.04, $\mathrm{p}=0.042$ ), decreased inhibition of FasL due to underexpression of miR21 could activate the apoptosis cascade through the initial step of the extrinsic apoptotic pathway. Moreover, miR21 has been reported to control the key regulators of apoptosis, such as SMAD proteins, which are the critical mediators of tumor growth factor beta (TGF- $\beta$ )-induced pro-apoptotic signaling. By binding to the 3'- untranslated region (3'-UTR) of SMAD7 mRNA, miR21 inhibits its translation [21]. Thus, decreased inhibition of SMAD7 mRNA could directly result in increased apoptosis.

Another anti-apoptotic miRNA was miR146a, and together with miR196b, functioned as a potent suppres- 
sor of Fas expression [22]. Forced miR146a expression causes autoimmune lymphoproliferative syndrome in mice via the downregulation of Fas in germinal center B cells $[22,23]$. FAS is a death receptor, and its upregulation through decreased miR146a expression levels (Table 2: 61.8-fold downregulation, $\mathrm{p}<0.001 ; 95 \% \mathrm{CI}$, $0.00001-0.04)$ might induce developmental meatal cells to undergo early apoptosis.

In addition, defects in cell migration or cell death could be attributed to underlying mechanisms for congenital diseases during the developmental process of embryogenesis [24, 25]. CHARGE syndrome is a multiple anomaly disorder that presents with a variety of phenotypes besides ear abnormalities [4]. Although 70\%-90\% of CHARGE syndrome case result from mutations in ATP-dependent chromatin remodeler CHD7 gene, Van Nostrand et al. (2014) showed surprising results using a knock-in mutant mouse strain expressing a stabilized and transcriptionally dead variant of the p53 tumor suppressor protein along with a wildtype p53 allele. They stated that the embryos represented characteristic phenotypes of CHARGE syndrome, including inner and outer ear malformations besides coloboma, heart outflow tract defects, and craniofacial defects [26]. They reported that p53 mutant protein could stabilize or hyperactivate wildtype $\mathrm{p} 53$ to inappropriately induce apoptosis during development. Moreover, they stated that due to CHD7 binding to the $\mathrm{p} 53$ promoter, thereby causing inappropriate $\mathrm{p} 53$ activation due to CHD7 loss, could contribute to CHARGE syndrome phenotypes [26]. According to these striking findings [26] and few published data supporting the critical role for p53 in developmental processes of ears [8], we speculated that dysregulation of p53 through the downregulation of apoptosis-controlling miRNAs (miR21, miR146, miR126, and miR222) by altering the timing or intensity of apoptosis, particularly in the outermost epithelial cells during auditory meatal development [8], may beget the ear abnormalities, including ear atresia and/or microtia (Fig. 4).

Furthermore, miR21 can affect cells by regulating major cascades of autophagy. Autophagy is a cellular pathway for the degradation of long-lived proteins and cytoplasmic organelles in its own lysosomal system in eukaryotic cells. Different signaling pathways, including

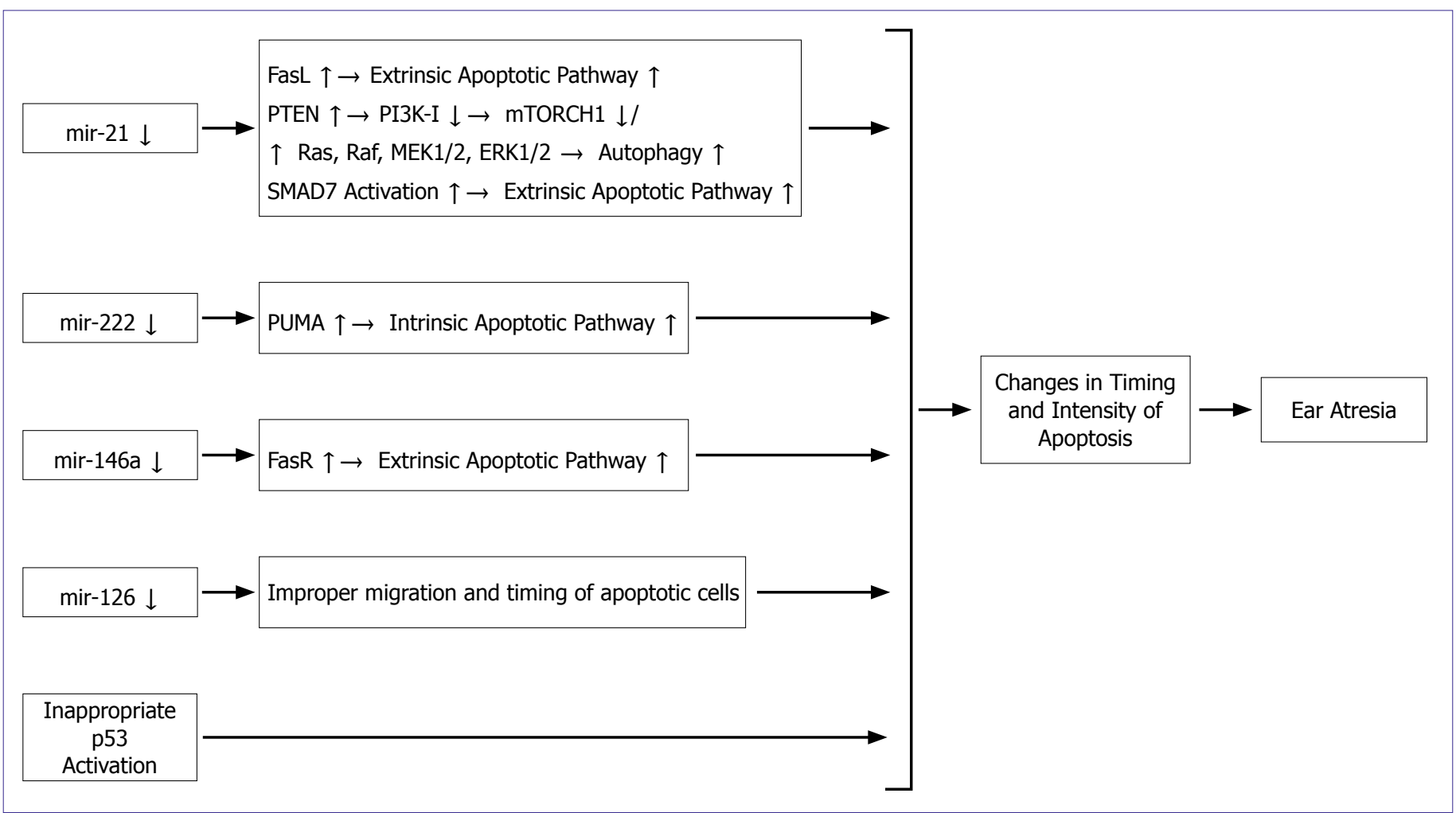

FIGURE 4. Representation of downregulated miRNAs resulting in ear atresia through the regulation of the apoptosis pathway. The significantly decreased expressions of miRNAs (miR21, miR146a, miR126, and miR222) may be related with apoptotic pathways in the pathogenesis of ear atresia. 
mammalian target of rapamycin (mTOR), phosphatidylinositol 3-kinase-I (PI3K-I)/PKB, Ras GTPases, calcium, and protein synthesis, play important roles in regulating autophagy $[27,28]$. PTEN, a negative regulator of the PI3K signaling pathway, is a hot target for a number of miRNAs, including miR21, which are involved in the regulation of several cancer types $[29,30]$. By the downregulation of miR21, PTEN more actively participates as a negative regulator of the $\mathrm{PI} 3 \mathrm{~K}$ signaling pathway [14]. Additionally, miR21 controls the major members of the Ras-Raf-1-MEK1/2-ERK1/2 signaling pathway $[31,32]$, particularly Ras expression in tumor suppression. Decreased expression of miR-21 may also serve as the negative regulator for autophagy either through $\mathrm{Ras}$ or PTEN within the cascade.

miR222 is encoded in tandem on the Xp11.3 chromosome in humans and is highly conserved in vertebrates similar as pri-miRNA of miR221 [33]. The tumor suppressor and angiogenesis genes have been identified as miR221/222 targets in several cancers [34]. Polliseno reported that miR221/222 family modulates the angiogenic activity of stem cell factor by targeting its receptor $c$-Kit and consequently promotes invasion and metastasis [28]. In other study, miR222 was reported to directly induce apoptosis by targeting the binding sites on mRNA 3'-UTR of mitochondrial apoptotic protein PUMA, which has recently been identified as a critical mediator of p53-associated apoptosis [35]. Hence, based on our results, we assumed that the downregulation of miR222 could be related to ear atresia by leading over-induced apoptosis through excessive activity of PUMA on mitochondrial apoptotic pathway. In case of the downregulation of PUMA repressing factors, such as miR222, more apoptosis than it necessitates may have occurred during external and middle ear development. At this point, p53 could be a good mediator associated with miR222 and PUMA; however, we found its expression significantly decreased in the ear atresia patient group (Fig. 2).

Thus, we assert that ear atresia may also develop due to increased apoptosis in concurrence with decreased autophagy. However, how can decreased autophagy result in ear atresia? PUMA is a direct transcriptional target of p53 and binds $\mathrm{Bcl}-2$, which is localized in the mitochondria, induces cytochrome $c$ release, and activates the rapid induction of apoptosis [36]. In our study, p 53 was significantly downregulated; therefore, we assumed that downregulation of miR222 may activate PUMA regardless of $\mathrm{p} 53$.
Finally, miR126 is a cell growth suppressor that targets IRS-137, and ectopic expression of miR126 in SGC7901 gastric cancer cells potently inhibits cell growth by inducing cell cycle arrest in the G0/G1 phase. miR126 may also lead to the inhibition of migration and invasion in vitro as well as tumorigenicity and metastasis in vivo [38]. Taken together, our results suggested that the possible causes of ear atresia may include underexpression of miR126 by improper migration and timing of apoptotic cells. Thus, decreased expressions of apoptosis-controlling miRNAs may lead to inappropriate apoptosis at inappropriate settling in the ear.

\section{CONCLUSION}

The pathways underlying the development of ear atresia with diverse phenotypes remain poorly understood. With our study, we for the first time reported the significantly decreased expressions of miRNAs (miR21, miR146a, miR126, and miR222) in the serum of patients with ear atresia, thus suggesting that miRNA-mediated control of apoptotic pathways may be responsible for the pathogenesis of ear atresia. Further studies are needed to identify the effects of miRNAs and their target genes in altered developmental processes.

Acknowledgment: This project was supported by the Research Fund of Istanbul Medeniyet University Project \# TSG-2013-333. We would like to thank Associate Prof. Serdar Ceylaner, MD, for his kind supply of the TP53 forward and reverse primers used in RT-PCR experiments. Among the authors, EA, EA, SY, ASK, UT, SY, and HG are members of the Project Machine as Medical Students. The authors declare no conflict of interest.

Conflict of Interest: The authors declare no conflict of interest.

Financial Disclosure: The authors declared that this study has received no financial support.

Authorship Contributions: Concept - I.A., S.Y., M.T.K., E.As., E.A.; Design - I.A., E.As., A.S.K.; Supervision - I.A., M.T.K.; Materials M.T.K., I.A.; Data collection \&/or processing - E.As., E.A., S.Y., A.S.K., U.T., S.Y., H.G., M.T.K., I.A.; Analysis and/or interpretation - E.As., E.A., S.Y., A.S.K., U.T., S.Y., H.G., I.A.; Writing - E.As., E.A., S.Y., U.T., M.T.K., I.A.; Critical review - E.A., I.A.

\section{REFERENCES}

1. Nager GT. Congenital aural atresia: anatomy and surgical management. Birth Defects Orig Artic Ser 1971;07:33-51.

2. Castilla EE, Orioli IM. Prevalence rates of microtia in South America. Int J Epidemiol 1986;15:364-8. [CrossRef]

3. Dostal A, Nemeckova J, Gaillyova R, Vranova V, Zezulkova D, Lejska $\mathrm{M}$, et al. Identification of 2.3-Mb gene locus for congenital aural atresia 
in 18 q22.3 deletion: a case report analyzed by comparative genomic hybridization. Otol Neurotol 2006;27:427-32. [CrossRef]

4. Jones KL, Jones MC, Del Campo M. Smith's reconnisable patterns of human malformations. 7th ed. Philadelphia: Elsevier Saunders; 2013.

5. Wright CG. Development of the human external ear. J Am Acad Audiol 1997;8:379-82.

6. Peck JE. Development of hearing. Part II. Embryology. J Am Acad Audiol 1994;5:359-65.

7. Kenna MA. Embryology and developmental anatomy of the ear. In: Bluestone CD, Stool SE, editors. 2nd ed. Philadelphia: WB Saunders; 1990, p. 77-87.

8. Nishizaki K, Anniko M, Orita Y, Masuda Y, Yoshino T, Kanda S, et al. Programmed cell death in the development of the mouse external auditory canal. Anat Rec 1998;252:378-82. [CrossRef]

9. Gerschenson LE, Rotello RJ. Apoptosis: a different type of cell death. FASEB J 1992;6:2450-5. [CrossRef]

10. Wyllie AH. Apoptosis (the 1992 Frank Rose Memorial Lecture). Br J Cancer 1993;67:205-8. [CrossRef]

11. Bartel DP. MicroRNAs: genomics, biogenesis, mechanism, and function. Cell 2004;116:281-97. [CrossRef]

12. Krol J, Loedige I, Filipowicz W. The widespread regulation of microRNA biogenesis, function and decay. Nat Rev Genet 2010;11:597-610.

13. Huang Y, Shen XJ, Zou Q, Wang SP, Tang SM, Zhang GZ. Biological functions of microRNAs: a review. J Physiol Biochem 2011;67:129-39.

14. Su Z, Yang Z, Xu Y, Chen Y, Yu Q. MicroRNAs in apoptosis, autophagy and necroptosis. Oncotarget 2015;6:8474-90. [CrossRef]

15. Rudnicki A, Isakov O, Ushakov K, Shivatzki S, Weiss I, Friedman LM, et al. Next-generation sequencing of small RNAs from inner ear sensory epithelium identifies microRNAs and defines regulatory pathways. BMC Genomics 2014;15:484. [CrossRef]

16. Kersigo J, D'Angelo A, Gray BD, Soukup GA, Fritzsch B. The role of sensory organs and the forebrain for the development of the craniofacial shape as revealed by Foxg1-cre-mediated microRNA loss. Genesis 2011;49:326-41. [CrossRef]

17. Li H, Kloosterman W, Fekete DM. MicroRNA-183 family members regulate sensorineural fates in the inner ear. J Neurosci 2010;30:325463. [CrossRef]

18. Soukup GA, Fritzsch B, Pierce ML, Weston MD, Jahan I, McManus MT, et al. Residual microRNA expression dictates the extent of inner ear development in conditional Dicer knockout mice. Dev Biol 2009;328:328-41. [CrossRef]

19. Li C, Hao S, Wang H, Jin L, Qing F, Zheng F, et al. MicroRNA expression profiling and target genes study in congenital microtia. Int J Pediatr Otorhinolaryngol 2013;77:483-7. [CrossRef]

20. Wang P, Zhuang L, Zhang J, Fan J, Luo J, Chen H, et al. The serum miR-21 level serves as a predictor for the chemosensitivity of advanced pancreatic cancer, and miR-21 expression confers chemoresistance by targeting FasL. Mol Oncol 2013;7:334-45. [CrossRef]

21. Li Q, Zhang D, Wang Y, Sun P, Hou X, Larner J, et al. MiR-21/Smad 7 signaling determines TGF- $\beta 1$-induced CAF formation. Sci Rep
2013;3:2038, [CrossRef]

22. Guo Q, Zhang J, Li J, Zou L, Zhang J, Xie Z, et al. Forced miR146a expression causes autoimmune lymphoproliferative syndrome in mice via downregulation of Fas in germinal center B cells. Blood 2013;121:4875-83. [CrossRef]

23. Li Z, Huang H, Chen P, He M, Li Y, Arnovitz S, Jiang X, et al. miR196b directly targets both HOXA9/MEIS1 oncogenes and FAS tumour suppressor in MLL-rearranged leukaemia. Nat Commun 2012;3:688.

24. Nussbaum RL, McInnes RR, Willard HF. Thompson and Thompson Genetics in Medicine. 7th ed. Saunders: 2007.

25. Mirkes PE. 2001 Warkany lecture: to die or not to die, the role of apoptosis in normal and abnormal mammalian development. Teratology 2002;65:228-39. [CrossRef]

26. Van Nostrand JL, Brady CA, Jung H, Fuentes DR, Kozak MM, Johnson TM, et al. Inappropriate p53 activation during development induces features of CHARGE syndrome. Nature 2014;514:228-32.

27. LeBlanc VC, Morin P. Exploring miRNA-Associated Signatures with Diagnostic Relevance in Glioblastoma Multiforme and Breast Cancer Patients. J Clin Med 2015;4:1612-30. [CrossRef]

28. Poliseno L, Tuccoli A, Mariani L, Evangelista M, Citti L, Woods K, et al. MicroRNAs modulate the angiogenic properties of HUVECs. Blood 2006;108:3068-71. [CrossRef]

29. Meng F, Henson R, Wehbe-Janek H, Ghoshal K, Jacob ST, Patel T. MicroRNA-21 regulates expression of the PTEN tumor suppressor gene in human hepatocellular cancer. Gastroenterology 2007;133:647-58.

30. Mouw JK, Yui Y, Damiano L, Bainer RO, Lakins JN, Acerbi I, et al. Tissue mechanics modulate microRNA-dependent PTEN expression to regulate malignant progression. Nat Med 2014;20:360-7. [CrossRef]

31. Deng M, Tang H, Zhou Y, Zhou M, Xiong W, Zheng Y, et al. miR$216 \mathrm{~b}$ suppresses tumor growth and invasion by targeting KRAS in nasopharyngeal carcinoma. J Cell Sci 2011;124:2997-3005. [CrossRef]

32. Hatley ME, Patrick DM, Garcia MR, Richardson JA, Bassel-Duby R, van Rooij E, et al. Modulation of K-Ras-dependent lung tumorigenesis by MicroRNA-21. Cancer Cell 2010;18:282-93. [CrossRef]

33. Garofalo M, Quintavalle C, Romano G, Croce CM, Condorelli G. miR221/222 in cancer: their role in tumor progression and response to therapy. Curr Mol Med 2012;12:27-33. [CrossRef]

34. Zhang CZ, Zhang JX, Zhang AL, Shi ZD, Han L, Jia ZF, et al. MiR221 and miR-222 target PUMA to induce cell survival in glioblastoma. Mol Cancer 2010;9:229. [CrossRef]

35. Zhang C, Zhang J, Zhang A, Wang Y, Han L, You Y, et al. PUMA is a novel target of miR-221/222 in human epithelial cancers. Int J Oncol 2010;37:1621-6.

36. Nakano K, Vousden KH. PUMA, a novel proapoptotic gene, is induced by p53. Mol Cell 2001;7:683-94. [CrossRef]

37. Zhang J, Du YY, Lin YF, Chen YT, Yang L, Wang HJ, et al. The cell growth suppressor, mir-126, targets IRS-1. Biochem Biophys Res Commun 2008;377:136-40. [CrossRef]

38. Feng R, Chen X, Yu Y, Su L, Yu B, Li J, et al. miR-126 functions as a tumour suppressor in human gastric cancer. Cancer Lett 2010;298:50-63. 